\title{
Bioactive compound profile of melon leaf extract (Cucumis melo L. 'Hikapel') infected by downy mildew
}

\author{
OZIE AKBAR PRATAMA ${ }^{1}$, WORO ANINDITO SRI TUNJUNG ${ }^{2}$, SUTIKNO ${ }^{3}$, BUDI SETIADI DARYONO ${ }^{1, \bullet}$ \\ ${ }^{1}$ Laboratory of Genetics and Breeding, Faculty of Biology, Universitas Gadjah Mada. J1. Teknika Selatan, Sekip Utara, Sleman 55281, Yogyakarta, \\ Indonesia. Tel./fax: +62-274-580839, `email: bs_daryono@mail.ugm.ac.id. \\ ${ }^{2}$ Laboratory of Biochemistry, Faculty of Biology, Universitas Gadjah Mada. Jl. Teknika Selatan, Sekip Utara, Sleman 55281, Yogyakarta, Indonesia \\ ${ }^{3}$ Laboratory of Plant Structure and Development, Faculty of Biology, Universitas Gadjah Mada. Jl. Teknika Selatan, Sekip Utara, Sleman 55281, \\ Yogyakarta, Indonesia
}

Manuscript received: 28 June 2019. Revision accepted: 31 October 2019.

\begin{abstract}
Pratama OA, Tunjung WAS, Sutikno, Daryono BS. 2019. Bioactive compound profile of melon leaf extract (Cucumis melo L. 'Hikapel') infected by downy mildew. Biodiversitas 20: 3448-3453. Plants express specific secondary metabolites (phytoalexin) in response to infection. Downy Mildew which infects melon plants (Cucumis melo L. 'Hikapel') caused by Pseudoperonospora cubensis Rostovtsev. Hikapel is one of superior melon cultivar produced from research in the Laboratory of Genetics, Faculty of Biology, Universitas Gadjah Mada, Yogyakarta, Indonesia. Bioactive content of Hikapel melon leaf under normal condition and infected by Downy Mildew yet to be researched. This research aims to screen bioactive profile of Hikapel leaf extract that has potential as phytomedicine. Leaf extract is compared between healthy plants and infected by Downy Mildew. Dried melon leaf was powdered using mortar and pestle. Leaf powder was extracted using hexane solvent. Extract was analyzed using a Shimadzu GCMS-QP2010S. Analysis found useful compounds like phytol, methyl ricinoleate, methyl linoleate, methyl stearate, and 1-hexacosanol. with therapeutic activity such as antibacterial, antifungal, antioxidant, antiinflammatory, antidiuretic, antidiarrheal, lowering blood LDL-C level, insulin level booster, antiproliferative, and anticancer. Some bioactive compounds are only synthesized in Hikapel melon leaf under stress conditions.
\end{abstract}

Keywords: Bioactive profile, downy mildew, GCMS, Hikapel, Pseudoperonospora cubensis

\section{INTRODUCTION}

Indigenously, plants have been widely used in traditional medicine, now becoming popular in modern society as alternatives to synthetic medicine (Chikezie et al. 2015). According to World Health Organization (WHO), more than $80 \%$ of world's population relies on traditional medicine as primary healthcare needs (WHO 1983). Even recent data shows that the use of traditional medicine in some African and Asian countries is on decline, traditional medicine still considered as important resources of medical alternatives in low-and middle-income countries (Oyebode et al. 2016). Plants synthesize various types of organic compounds that divided into primary and secondary metabolites which vary among species (Buchanan et al. 2000; Bennet and Wallsgrove 1994). Secondary metabolites (SMs) has numerous functions, like protecting the plants from herbivore and microbes infection, act as an attractant for pollinator insects (Kennedy and Wightman 2011; Wink 2018), attractant for seed-spreaders animals (Wink 2018), allelopathy agents (Kennedy and Wightman 2011), and growth regulator (Pagare et al. 2015) Secondary metabolites are synthesized from primary metabolites such as acetate, pyruvate, and amino acids (Sato 2014). Secondary metabolites biosynthesis is strongly affected by environmental changes, herbal predator, pathogens, and genetic trait of the plants (Pavarini et al. 2012; Kennedy and Wightman 2011). Typically, secondary metabolites that have pharmacological or toxicological effects in humans or animals are called bioactive compounds (Bernhoft 2010).

Phytomedicine is generally cheaper and cause lesser side effects than synthetic drugs. Research in plant medicine has led to new drug discoveries, such as anticancer chemotherapies (Chikezie et al. 2015). Modern research reveals more than 170.000 known secondary metabolites, and yet there's more to be discovered (Delgoda and Murray 2017). By increasing knowledge of plant secondary metabolites over last two decades, human can extract therapeutic compounds that are difficult to artificially synthesized or not currently possible (Bhatia 2015; Belščak-Cvitanović et al. 2018).

Phytopathogenic fungi infection could induce production of secondary metabolites (Ribera and Zuñiga 2012). According to Bernhoft et al. (2008), bioactive compounds in plants can be defined as secondary metabolites with pharmacological or toxicological functions towards humans and animals. These compounds are divided into 3 large groups: alkaloids, flavonoids, and terpenoids.

Alkaloids are found in bacteria, fungi, plants, and animals. Alkaloids are present approximately in 300 plant families, although some of the compounds are specifically found in specific pa*rt of the plant (Cushnie et al. 2014). The functions of alkaloids are as a chemical defense to prevent parts of the plants consumed by insects or animals (phytoalexins) and inhibit or kill microbes (Bernhoft 2010). 
Many kinds of alkaloids are toxic for insect-like nicotine from tobacco, which is the first insecticide used by humans (Steppuhn et al. 2004). The herbivore that consumes the parts of the plant will make the plant stimulates certain alkaloids biosynthesize (Buchanan et al. 2000). Flavonoids consist of many different components and have wide functions. The interaction between plants and animals can occur due to the presence of flavonoids, either to invite or prevent pathogens and herbivores. Colors in flowers and fruits attract pollinators and animal seed dispersers by flavonoid compounds such as pelargonidin, delphinidin, and cyanidin (Ferreyra et al. 2012). Several types of flavonoids also work to protect radiation from UV-B (Bernhoft 2010; Buchanan et al. 2000). Terpenoids are hydrocarbon compounds with formula $\left(\mathrm{C}_{5} \mathrm{H}_{8}\right)_{n}$. Naturally, terpenoids are found in plants and have many structural variations. Terpenoids functions in plants are to attract pollinators, inhibit competing plants, and antimicrobial activity (Bernhoft 2010). One of that plant's purposes to produce terpenoids is as a defense from fungi, so that the plants that able to synthesize certain terpenoids are resistant with fungal attacks (Bohlmann and Keeling 2008).

Melon (Cucumis melo L.) is a fruit-bearing plant of Cucurbitaceae family from Persia in the Mediterranian, on the border of West Asia, Europe, and Africa (Parle and Kulwant 2011). Cucumis melo L. cv. Hikapel is a new cultivar of melon developed by Laboratory of Genetics and Breeding, Faculty of Biology, Universitas Gadjah Mada (UGM), Yogyakarta, Indonesia. Melon cv. Hikapel has non-netted skin, orange-fleshed honeydew melon. Hikapel fruit contains bioactive compounds such as ascorbic acid, phenolic, flavonoid, and carotenoid (Daryono and Nofriarno 2018; Wulandari et al. 2016).

Other than the fruit, melon plant's stem have numerous advantages. Chinese traditional herbs use the powder of melon's stem as the main staple to cure indigestion, acute hepatitis, liver cirrhosis, and cancer (Chen et al. 2009). Analysis of melon's stem extract content shows a large number of volatile components: triterpenoids, sterol, and flavonoids. The cucurbitacin has been proven to have cytotoxic and anti-cancer activity. From pharmacological side, this compound is hepatoprotective, can be used as laxative, anti-microbial, anti-inflammatory, and antifertility activity (Chen et al. 2009).

\section{MATERIALS AND METHODS}

\section{Procedures \\ Plantation}

Research was done from September through December 2015. Hikapel seeds were provided by Laboratory of Genetics and Breeding, Faculty of Biology, Universitas Gadjah Mada (UGM), Yogyakarta, Indonesia. Healthy Hikapel plants were field-planted in Polengan, Madurejo, Yogyakarta. Naturally infected Hikapel plants by Downy Mildew were field-planted in PIAT UGM, Yogyakarta, Indonesia.

\section{Hexane extraction}

Extraction of bioactive compounds from leaf powder was done in Plant Structure and Development Laboratory. Tools needed for leaf sample extraction are mortar and pestle, beaker $100 \mathrm{ml}$, Erlenmeyer $50 \mathrm{ml}$, oven, analytical scale, and GCMS-QP2010S Shimadzu. Materials needed are healthy and infected Hikapel powdered leaf and nhexane.

Plant bioactive compound was extracted by maceration method. The samples were sliced and dried in an oven at $57^{\circ} \mathrm{C}$ for 24 hours. After drying, the sample is crushed until smooth and weighed as much as 0.5 gr. Dried sample was extracted with $25 \mathrm{ml}$ hexane solvent, stirred and allowed to stand for 24 hours. Solvent was filtered with filter paper 3 times and dried until it evaporated and formed a precipitate at the bottom of the porcelain plate. Precipitate was redissolved in $5 \mathrm{ml}$ of $\mathrm{n}$-hexane.

\section{GC-MS analysis}

Bioactive content analysis using GC-MS was done in Organic Chemistry Laboratory, Faculty of Mathematics and Natural Sciences, UGM, Yogyakarta. Three $\mu 1$ of the solution was injected in a Shimadzu GCMS-QP2010S gas chromatography, with initial temperature of $100^{\circ} \mathrm{C}$ and final temperature of $300^{\circ} \mathrm{C}$. The type of column used is Agilent HP $1 \mathrm{MS}$, the type of detector is FID set to $300^{\circ} \mathrm{C}$, the injector temperature is $300^{\circ} \mathrm{C}$ and the carrier gas is helium.

\section{Data analysis}

The result of gas chromatography is a compound chromatogram profile. Spectra from GC-MS results are compared with WILEY229.LIB and NIST62 library containing spectra database, so it can be seen the possibility of the compounds contained in the sample.

\section{RESULTS AND DISCUSSION}

In this study, n-hexane solvents were used, so that the detected compounds belong to the fatty acid and terpenoid groups. Fatty acids are the primary metabolites of plants, while terpenoids are included in secondary metabolites. Figure 1 shows gas chromatography chromatogram analysis showing 21 detected peaks on the healthy leaves and 19 peaks on the infected leaves.

The compounds representing each peak from Figure 1 are presented in Table 1. Based on the results of GC and GC-MS analysis, there is a difference in chemical profile between healthy melon leaf extracts versus those infected. This data shows that there's some compound only synthesized under fungal infection by Pseudoperonospora cubensis.

Chemical profile of melon leaf extracts shown that there are 17 and 19 different compounds detected in healthy and infected leaf respectively. Differences in the number and type of compounds can occur due to infected leaves, a certain metabolic response that aims to fight the infecting fungi. Plant responded against infection in the form of production of certain secondary metabolites that have antimicrobial activity. 


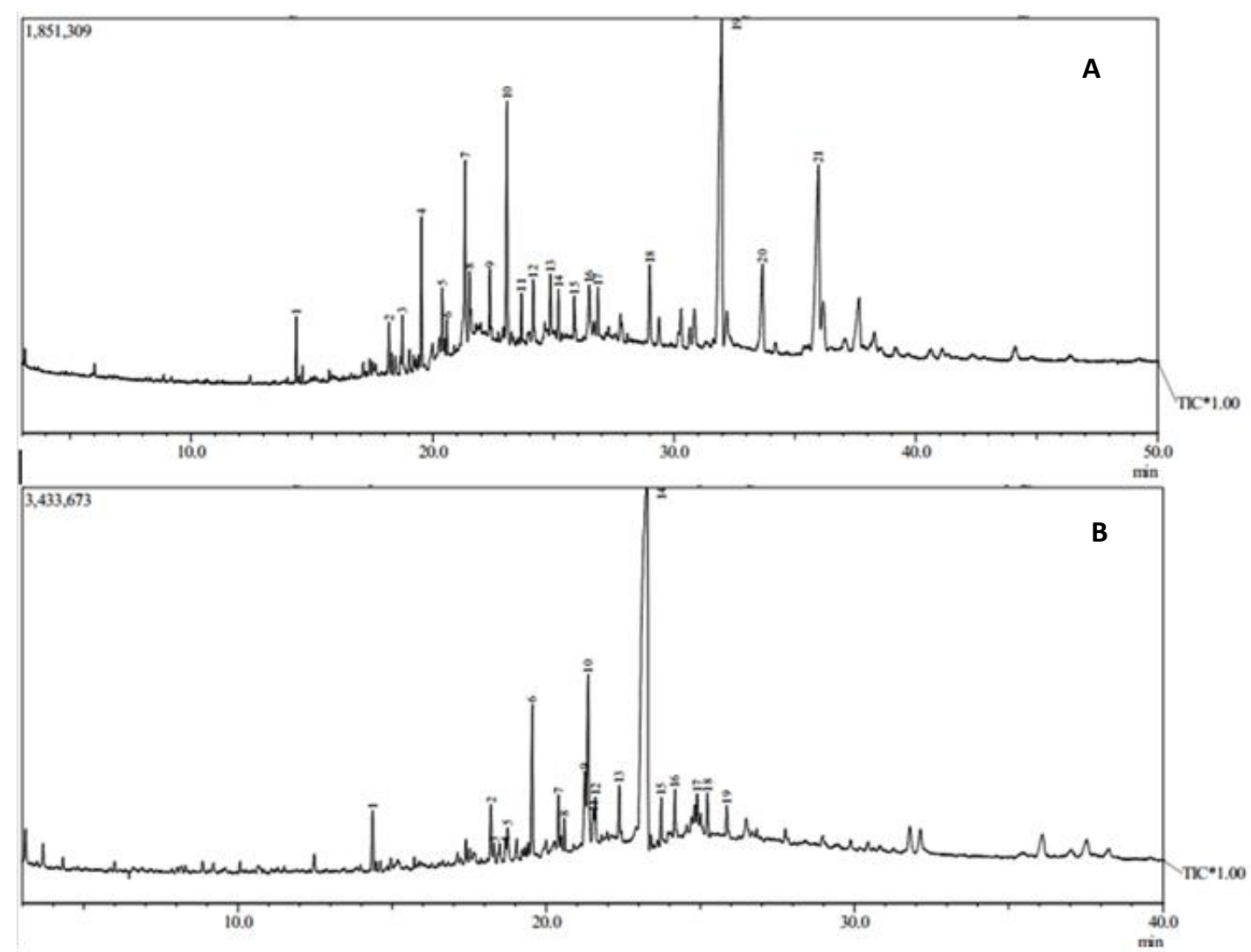

Figure 1. GC or GC/MS Chromatograms of the healthy leaf extract (A) and the infected (B)

Based on the results of GC-MS analysis in Table 1, there are differences in chemical profile between healthy melon leaf extract compared to those infected. Chemical profile of the melon leaf extract shows there are 17 and 19 different compounds detected in healthy and infected leaf respectively. Differences in the number and type of compounds can occur due to infected leaves, a certain metabolic response that aims to fight the infection.

Some compounds detected in the leaf extract have medicinal properties that could be potential as phytomedicine. Phenol, 2,4-bis (1,1-dimethyl ethyl) is an alkylated phenol and it is found in both healthy and infected melon leaf extract. According to Dehpour et al. (2012), this compound has antibacterial activity against 5 bacteria strains (Proteus mirabilis, Enterobacter cloacae, Klebsiella pneumonia, Staphylococcus aureus, and Bacillus subtilis). This compound also has antifungal activity that reduced growth of Aspergillus and Phytophthora cinnamomi at a concentration of $100 \mu \mathrm{g} / \mathrm{ml}$ (RangelShancez et al. 2013).

Terpenoid compounds found in leaf extract are neophytadiene, phytol, 4,8,12,16-tetramethylheptadecan-4olide, and 6,10,14-trimethyl-2-pentadecanone. From four terpenoid detected, all compound has the same area compared between healthy and infected, except 6,10,14trimethyl-2-pentadecanone that is only found in infected leaf. Neophytadiene is a potent antimicrobial and antiinflammatory compounds. This terpenoid also has antifungal and antioxidant properties (Venkata et al. 2012). According to Pejin et al. (2014), phytol has antimicrobial activity against Enterococcus faecalis better than Gentamicin or Ampicillin in vitro. Phytol also has effect to boost insulin level in type-2 diabetes (Venkata et al. 2012). It has anticancer and antidiuretic activities as described by Abdel-Aal et al. (2015). Phytol can act as antinociceptive agent when administered intraperitoneally (i.p.) to mice exposed to chemical and thermal nociception. It also has antioxidant activity in vitro to remove hydroxyl radicals, nitric oxide, and prevent thiobarbituric acid reactive substances or TBARS (de Menezes et al. 2013). Research demonstrated by Song and Cho (2015) shows that phytol induces apoptosis and ROS-mediated protective autophagy in human gastric adenocarcinoma (AGS) cells. Parasitic activity of phytol as described by Moraes et al. (2014) showed it can decrease motor activity, reducing eggs produced, and tegumental damage of $S$. mansoni. Significant reduction of $S$. mansoni by phytol offers potential substitutes to global reliance on Praziquantel, single drug for schistosomiasis. According to Perumal et al. (2014), 4,8,12,16-tetramethylheptadecan-4-olide has potential as anticancer medicine because it agonize Peroxisome Proliferation-Activated Receptor gamma (PPAR $\gamma$ ), a nuclear receptor family expressed in several types of cancer cells. 6,10,14-trimethyl-2-pentadecanone, the only terpenoid detected in infected leaf has antibacterial and antifungal activity (Balogun et al. 2017). 
Table 1. Chemical profile comparison between healthy melon cv. Hikapel leaf extract and that infected by downy mildew

\begin{tabular}{|c|c|c|c|c|}
\hline \multirow{2}{*}{ Molecule } & \multicolumn{2}{|c|}{ Area \% } & \multicolumn{2}{|r|}{ Information } \\
\hline & Healthy & Infected & Group & Function \\
\hline Phenol, 2,4-bis (1,1-dimethyl ethyl) & 2.13 & 2.44 & Phenol & $\begin{array}{l}\text { Antibacterial (Dehpour et al. 2012), antifungal } \\
\text { (Rangel-Shancez et al. 2013) }\end{array}$ \\
\hline Neophytadiene & 1.57 & 1.25 & Diterpenoid & $\begin{array}{l}\text { Antimicrobial, antifungal, anti-inflammatory, } \\
\text { antioxidant (Venkata et al. 2012) }\end{array}$ \\
\hline Methyl hexadecanoate & 5.03 & 6.1 & Fatty acid methyl ester & Antifungal and antioxidant (Pinto et al. 2017) \\
\hline 1-docosene & 1.91 & 1.89 & Hydrocarbon & - \\
\hline Isopropyl palmitate & 1.29 & 1.44 & Fatty acid & - \\
\hline Phytol & 1.51 & 1.46 & Diterpenoid & $\begin{array}{l}\text { Antimicrobial, (Pejin et al. 2014), boost insulin } \\
\text { level (Venkata et al. 2012), anticancer, } \\
\text { antidiuretic, precursor (Abdel-Aal et al. 2015) }\end{array}$ \\
\hline 1-octadecene & 1.8 & 1.67 & Hydrocarbon & - \\
\hline Methyl ricinoleate & 10.03 & 59.68 & Fatty acid methyl ester & Antioxidant (Oloyede 2012) \\
\hline $\begin{array}{l}4,8,12,16 \text {-Tetramethylheptadecan- } \\
\text { 4-olide }\end{array}$ & 1.52 & 1.67 & Diterpenoid & Possible anticancer (Perumal et al. 2014) \\
\hline 1-nonadecene & 1.74 & 1.52 & Hydrocarbon & - \\
\hline 2-Palmitoylglycerol & 2.3 & 1.05 & Glycerol & - \\
\hline Di-n-octyl phthalate & 1.5 & 1.4 & Aromatic ester & - \\
\hline 1-nonadecene & 1.11 & 0.87 & Hydrocarbon & - \\
\hline 5-Octadecene & 1.57 & - & Hydrocarbon & - \\
\hline Methyl 10-octadecenoate & 6.01 & - & $\begin{array}{l}\text { Carbon compound with } \\
\text { hydroxyl group }\end{array}$ & - \\
\hline 1-Monolinolein & 2.08 & - & Glyceride & - \\
\hline Tetratetracontane & 56.92 & - & Hydrocarbon & - \\
\hline 1-Hexacosanol & - & 2.11 & Fatty alcohol & Lowering LDL-C (Jones and Jew 2016) \\
\hline Heptadecane & - & 0.62 & Hydrocarbon & Antiinflammatory (Kim et al. 2013) \\
\hline 6,10,14-trimethyl-2-pentadecanone & - & 0.79 & Sesquiterpenoid & $\begin{array}{l}\text { Antibacterial and antifungal (Balogun et al. } \\
\text { 2017) }\end{array}$ \\
\hline Methyl linoleate & - & 3.67 & Fatty acid & Antioxidant and antifungal (Pinto et al. 2017) \\
\hline Methyl stearate & - & 9.01 & Fatty acid methyl ester & $\begin{array}{l}\text { Antifungal (Pinto et al. 2017), antidiarrheal and } \\
\text { antiproliferative (Kuppuswamy et al. 2013) }\end{array}$ \\
\hline Methyl stearate & - & 1.36 & Fatty acid methyl ester & $\begin{array}{l}\text { Antifungal (Pinto et al. 2017), antidiarrheal and } \\
\text { antiproliferative (Kuppuswamy et al. 2013) }\end{array}$ \\
\hline
\end{tabular}

Fatty acid was also detected in the leaf extract. Isopropyl palmitate was detected in both healthy and infected leaf extract, while methyl linoleate was only detected in infected leaf. Methyl linoleate has antioxidant and antifungal properties (Pinto et al. 2017). Fatty acid can be synthesized as plant responses to overcome fungal infection which targets fungal cell membrane. Fatty acid with antifungal activity can enter and become part of the lipid bilayer of fungi cells. This can disrupt the fungi cell membrane, leading to increased membrane fluidity, disrupt cell integrity, and eventually rupturing membrane (Avis and Bélanger 2001).

Fatty Acid Methyl Ester (FAMEs) detected in Hikapel melon leaf were methyl hexadecanoate, methyl ricinoleate, and methyl stearate. Methyl hexadecanoate which was detected both in healthy and infected melon leaves has area $5.03 \%$ and $6.1 \%$ respectively. It has no significant area increase compared to methyl ricinoleate from $10.03 \%$ to $59.68 \%$ in healthy and infected leaf extract respectively. Methyl stearate was only found in infected leaf with area $10.37 \%$. A research conducted by Pinto et al. (2017) shown that methyl hexadecanoate has antifungal activity against Paracoccicoides spp., Candida glabrata, C. krusei, and $C$. parapsilosis. They also reported that this compound also has antioxidant activity. Methyl ricinoleate has antioxidant activity proved by three methods: lipid peroxidation by ferric thiocyanate, free radical scavenging on $\mathrm{DPPH}$, and hydroxyl radical generated from hydrogen peroxide (Oloyede 2012). Methyl stearate has antifungal (Pinto et al. 2017), anti-diarrheal and anti-proliferative (Kuppuswamy et al. 2013).

There is only one compound (1-hexacosanol) belong to fatty alcohol group found in Hikapel melon leaf extract. 1Hexacosanol was detected only in infected leaf. According to Jones and Jew (2016), hexacosanol and other mixture of polycosanols significantly lowering blood Low-Density Lipoprotein carrying Cholesterol (LDL-C) level. This fatty alcohol suppresses HMG-CoA reductase and increases cellular LDL-C uptake.

According to Table 1. seven hydrocarbon compounds were detected in Hikapel leaf extract, but only one compound has therapeutic properties. Heptadecane was only found in infected leaf $(0.62 \%)$, and has antiinflammatory activity against aged kidney tissues (Kim et al. 2013). 
In conclusion, detectable compounds in healthy leaves with infected leaves vary in number and type. This shows plants are changing their metabolism in response to infection. Analysis found compounds with therapeutic activity such as antibacterial, antifungal, antioxidant, antiinflammatory, antidiuretic, antidiarrheal, lowering blood LDL-C level, insulin level booster, antiproliferative, and anticancer. Some bioactive compounds were only synthesized in Hikapel melon leaf under stress conditions.

In conclusion, Cucumis melo L. 'Hikapel' is a melon cultivar produced by Laboratory of Genetics, Faculty of Biology. GC-MS analysis of healthy leaf extract and Downy Mildew-infected leaf extract with hexane showed 23 chemical components. There are differences in numbers and types of detected components between healthy and infected leaves. Some phytochemical compounds detected have therapeutic functions such as antibacterial, antifungal, antioxidant, antiinflammatory, antidiuretic, antidiarrheal, lowering blood LDL-C levels, insulin level booster, antiproliferative, and anticancer.

\section{ACKNOWLEDGEMENTS}

This research was supported by Laboratory of Genetics, Faculty of Biology, Universitas Gadjah Mada (UGM), Yogyakarta, Indonesia who provided Melon cv. Hikapel plants. Special thanks to DITLIT UGM for funding this research 'Hibah Biovir PUPT UGM' year 2018-2019.

\section{REFERENCES}

Abdel-Aal EI, Amany MH, Jelan M. 2015. Successive solvent extraction and GC-MS analysis for the evaluation of the phytochemical constituent of the filamentous green algae Spirogyra longata. Egypt J Aquat Res (41): 233-246. DOI: 10.1016/j.ejar.2015.06.001

Avis TJ, Bélanger RR. 2001. Specificity and mode of action of the antifungal fatty acid cis-9-heptadecenoic acid produced by Pseudozyma flocculosa. Appl Environ Microbiol 67: 956-960.

Balogun OS, Olukayode SA, Ayansola JA. 2017. Hexahydrofarnesyl acetone-rich extractives from Hildegardia barteri. J Herbs Spices Med Plants. DOI: 10.1080/10496475.2017.1350614

Belščak-Cvitanović A, Valinger D, Benković D, Tušek AJ, Jurina T, Komes D, Kljusurić JG. 2018. Integrated approach for bioactive quality evaluation of medicinal plant extracts using HPLC-DAD, spectrophotometric, near-infrared spectroscopy and chemometric techniques. Intl J Food Prop. DOI: 10.1080/10942912.2017.1373122.

Bennet RN, Wallsgrove RM. 1994. Secondary metabolites in plant defense mechanism. New Phytol 127: 617-633.

Bernhoft A. 2008. Bioactive compounds in plants-benefits and risks for man and animals. Proceedings from a symposium held at The Norwegian Academy of Science and Letters. Oslo. 13-14 November 2008

Bernhoft A. 2010. A Brief Review on Bioactive Compounds in Plants. The Norwegian Academy of Science and Letters, Oslo.

Bhatia S. 2015. Modern Applications of Plant Biotechnology in Pharmaceutical Sciences. Elsevier Inc., Amsterdam.

Bohlmann J, Keeling CI. 2008. Terpenoid biomaterials. Plant J 54: 656669.

Buchanan BB, Wilhelm G, Russel LJ. 2000. Biochemistry \& Molecular Biology of Plants. John Wiley \& Sons, Rockville.

Chen C, Shigao Q, Liguang L, Weimin Z. 2009. Cucurbitane-type triterpenoids from the stems of Cucumis melo. J Nat Prod 72: 824829.
Chikezie PC, Ibelbugem CO, Mbagwu FN. 2015. Bioactive principles from medical plants. Res J Phytochem 9 (3): 88-155. DOI: 10.3923/rjphyto.2015.88.115.

Cushnie TPT, Benjamart C, Andrew JL. 2014. Alkaloids: An overview of their antibacterial, antibiotic-enhancing, and antivirulence activities. Int J Antimicrob Agents 44 (2014): 377-386.

Daryono BS, Nofriarno N. 2018. Pewarisan karakter fenotip melon (Cucumis melo L. 'Hikapel Aromatis') hasil persilangan $\bigcirc$ 'Hikapel' dengan 'Hikadi Aromatik'. Biosfera. DOI: 10.20884/1.mib.2018.35.1.586. [Indonesian]

de Menezes PSCC, Mirian SS, Vanine GM, Luciana MC, Antonia ACDA, Guilherme ALDO, Jessica PC, Damiao PDS, Rivelilson MDF, Reinaldo NDA. 2013. Antinociceptive and antioxidant activities of phytol in vivo and in vitro models. Neurosci J. DOI: $10.1155 / 2013 / 949452$.

Dehpour AA, Yousefian M, Jafary KSA, Koshmoo M, Mirzanegad S, Mahdavi V, Mousavi SE, Shirzad E, Afzali M, Javad BMJ, Olyaei JE, Yahyapor MK. 2012. Antibacterial activity and composition of essential oils of flower Allium rotundum. Adv Environ Biol 6 (3): 1020-1025.

Delgoda R, Murray JE. 2017. Pharmacognosy: Fundamentals, Applications and Strategies. Elsevier Inc., Amsterdam.

Ferreyra MLF, Rius SP, Casati P. Flavonoids: biosynthesis, biological functions, and biotechnological applications. Front Plant Sci. DOI:10.3389/fpls.2012.00222.

Jones PJH, Jew S. 2016. Functional Dietary Lipids: Food Formulation, Consumer Issues and Innovation for Health. Woodhead Publishing, Chambridge, UK

Kennedy DO, Wightman EL. 2011. Herbal extracts and phytochemicals: plant secondary metabolites and the enhancement of human brain function. Adv Nutr 2: 32-50.

Kim DH, Min HP, Yeon JC, Ki WC, Cha HP, Eun JJ, Hye JA, Byung PY, Hae YC. 2013. Molecular study of dietary heptadecane for the antiinflammatory modulation of NF-kB in the aged kidney. PLoS ONE 8 (3): e59316. DOI: 10.1371/journal.pone.0059316.

Kuppuswamy KM, Bhavana J, Sumathy A. 2013. GC-MS analysis of chloroform extract of Croton bonplandianum. Intl J Pharm Bio Sci 4 (4): 613-617.

Moraes J, Rosimeire NO, Jessica PC, Antonio LGJ, Damiao PS, Rivelilson MF, Silmara MA, Pedro LSP. 2014. Phytol, a diterpene alcohol from chlorophyll, as a drug against neglected tropical disease Schistosomiasis mansoni. PLoS Negl Trop Dis 8 (1): e2617. DOI:10.1371/journal.pntd.0002617.

Oloyede GK. 2012. Antioxidant activities of methyl ricinoleate and ricinoleic acid dominated Ricinus communis seed extract using lipid peroxidation and free radical scavenging methods. Res J Med Plant 6 (7): 511-520. DOI: 10.3923/rjmp.2012.511.520.

Oyebode O, Kandada N, Chilton PJ, Lilford RJ. 2016. Use of traditional medicine in middle-income countries: a WHO-SAGE study. Health Policy Plann. DOI:10.1093/heapol/czw022.

Pagare S, Bhatia M, Tripathi M, Pagare S, Bansal YK. 2015. Secondary metabolites of plants and their role: overview. Curr Trends Biotech Pharm 9 (3): 293-304.

Parle M, Kulwant S. 2011. Musk melon is eat-must melon. Int Res J Pharm 2 (8): 52-57.

Pavarini DP, Pavarini SP, Niehues M. 2012. Exogenous influences on plant secondary metabolite level. Anim Feed Sci Technol 176 (2012): 5-16. DOI: 10.1016/j.anifeedsci.2012.07.002.

Pejin B, Kartali T, Stanimirovic B, Karaman M. 2014. Phytol may inspire new medical foods for the treatment of heart disease. Asian J Chem 26 (23): 8261-8262.

Perumal PC, Sundaram S, Prabhakaran P, Balasubramanian V, Palanirajan A, Thangarajan S, Ramasamy V, Jeya SS, Veliyur KG. 2014. Identification of novel PPAR $\gamma$ agonist from GC-MS analysis of ethanolic extract of Cayratia trifolia (L.): a computational molecular simulation studies. J Appl Pharm Sci. DOI: 10.7324/JAPS.2014.40902.

Pinto MEA, Sthefane GA, Marcela IM, Nivea SA, Caroline ML, Carlos AR, Ezequias PS, Susana J, Luciana ARSL. 2017. Antifungal and antioxidant activity of fatty acid methyl ester from vegetable oils. An Acad Bras Cienc. DOI: 10.1590/0001-3765201720160908.

Rangel-Shancez G, Elda C, Ernesto G. 2013. Avocado roots treated with salicylic acid produce phenol-2,4-bis (1,1-dimethyl ethyl), a compound with antifungal activity. J Plant Physiol 171 (2014): 189. 198. DOI: 10.1016/j.jplph.2013.07.004. 
Ribera AE, Zuñiga G. 2012. Induced plant secondary metabolites for phytopathogenic fungi control: a review. J Soil Sci Plant Nutr 12 (4) 893-911.

Sato F. 2014. Plant Secondary Metabolism. John Wiley \& Sons Ltd, Chichester.

Song YW, Somi KC. 2015. Phytol induces apoptosis and ROS-mediated protective autophagy in human gastric adenocarcinoma AGS cells. Biochem Anal Biochem. DOI: 10.4172/2161-1009.1000211.

Steppuhn A, Gase K, Krock B, Halitschke R, Baldwin IT. 2004 Nicotine's defensive function in nature. PLoS Biol DOI:10.1371/journal.pbio.0020217.
Venkata RB, Samuel LA, Pardha SM, Narashima RB, Naga VKA, Sudhakar M, Radhakrishnan TM. 2012. Antibacterial, antioxidant activity and GC-MS analysis of Eupatorium odoratum. Asian J Pharm Clin Res 5 (2): 99-106.

WHO. 1983. Traditional Medicine and Health Care Coverage. WHO Geneva, Switzerland.

Wink M. 2018. Plant secondary metabolites modulate insect behaviorsteps toward addiction? Front Physiol 9: 364. DOI: 10.3389/fphys.2018.00364.

Wulandari P, Daryono BS, Supriyadi. 2016. The effect of ripening stages on the antioxidant potential of melon (Cucumis melo L.) cultivar Hikapel. AIP Conf Proc. DOI: 10.1063/1.4985430. 